\title{
Where two oceans meet: distribution and offshore interactions of great-winged petrels Pterodroma macroptera and Leach's storm petrels Oceanodroma leucorhoa off southern Africa
}

\author{
Kees C. J. Camphuysen
}

Received: 16 July 2006/Revised: 20 March 2007 / Accepted: 20 March 2007/Published online: 12 May 2007

(C) Dt. Ornithologen-Gesellschaft e.V. 2007

\begin{abstract}
During seabird surveys off southern Africa, great-winged petrel Pterodroma macroptera and Leach's storm petrel Oceanodroma leucorhoa were widespread and relatively common. Similar aerial displays, frequent (social) interactions, a tendency to "huddle" in tight (mixed) gatherings and interactions during foraging inspired a study of their behaviour and distribution. Both species peaked at $>2,000$-m-deep ocean waters, with lower densities over the shelf and with Leach's storm petrels (ca. $0.5 \mathrm{~km}^{-2}$ ) twice as abundant as great-winged petrels (ca. $0.25 \mathrm{~km}^{-2}$ ). The results suggest half a million great-winged petrels and well over a million Leach's storm petrels occurring over deep waters off southern Africa. Active fishing vessels elevated background densities of petrels in some areas, indicating the utilisation of discarded material, but in most areas hardly any fisheries were encountered and on the shelf with no discernable effect on petrel densities. Both species showed an association with meso-scale hydrographic features in the Agulhas current retroflection region. High densities of Leach's storm petrels occurred in offshore areas with steep salinity and sea surface temperature gradients. No such tendency was found in greatwinged petrels. Great-winged petrels spent relatively little time feeding during daylight (10.3\% of birds observed) in comparison to Leach's storm petrels $(66.2 \%)$, but were frequently seen to join feeding Leach's storm petrels where they profited from the searching skills of Leach's. Both species performed displays as individuals, in pairs, in lar-
\end{abstract}

Communicated by F. Bairlein.

K. C. J. Camphuysen ( $₫)$

Royal Netherlands Institute for Sea Research (Royal NIOZ), P.O. Box 59, 1790 AB Den Burg, Texel, The Netherlands

e-mail: camphuys@nioz.nl; kees.camphuysen@wxs.nl ger groups and in mixed-species groups. Tight gatherings of petrels swimming at sea (huddling) occurred, consisting either of one species or both. When disturbed, such flocks would disperse after take off and often engage in aerial displays. It is speculated that the formation of these flocks is part of the anti-predator strategy of petrels against attacks from under water.

Keywords Offshore behaviour · Inter-specific interactions · Offshore distribution · Marine habitats

\section{Introduction}

"Two-thirds of our planet is covered by sea and it is the sea, not the land, that is the domain of the petrels, par excellence the seabirds of the open ocean" (Brooke 2004). It is therefore surprising, and obviously mostly for logistic reasons, that most published accounts on the petrel family are based on studies at breeding colonies on land. For as far as their offshore distribution is currently known, let alone understood, hardly any information is available on the natural behaviour of petrels at sea. Recent technological advances have produced truly groundbreaking data on the offshore distribution and feeding capabilities of pelagic seabirds, notably of the albatrosses and larger petrels (Freeman et al. 1997; Catard et al. 2000; Birdlife International 2004). For smaller species, such as the smaller petrels, similar study opportunities have yet to be developed. Their offshore distribution, foraging habitats and feeding activities can only be derived from visual observations. In addition, tracking studies are essentially species-specific and individual-based and sample sizes are often small. Data on interspecific interactions of seabirds and other top-predators at sea cannot, at least for the moment, be collected 
with electronic devices. Offshore ship-based surveys offer ample opportunities to study the behaviour at sea (Harrison et al. 1991; Speckman et al. 2003; Camphuysen and Garthe 2004). However, even although many more systematic seabird surveys have been conducted in recent decades, since Murphy's "Oceanic Birds of South America" (1936), few first-hand reports have been published on the offshore behaviour of pelagic seabirds at sea. This is a great pity, for the value of recent tracking data would be greatly enhanced when the data were compared and combined with results from visual observations. Data on behavioural aspects derived from loggers could be seen as complementary to visual observations and vice versa.

An opportunity to study the offshore distribution of pelagic seabirds off southern Africa arose when the research vessel Pelagia worked an area between Walvisbaai (Namibia) and Cape Town (South Africa) in January-March 2000 and 2001. The seabird work was attached to the Royal Netherlands Institute for Sea Research's (Royal NIOZ) Mixing of Agulhas Rings Experiment programme (MARE). This project was meant to determine the proportion of Agulhas current leakage that contributes to the northward branch of the ocean's thermohaline circulation (THC). As part of that study, a selected Agulhas ring (an eddy, a roughly circular water mass originating from the Indian Ocean travelling through the South Atlantic) was examined at different stages of its non-linear decay over a period of 1 year. The study area was thus situated where two oceans meet: the Atlantic Ocean and the Indian Ocean (International Hydrographic Bureau 1953). Most work was done over very deep waters $(>2,000 \mathrm{~m}$ depth), well away from the continental shelf, in areas where few fishing fleets were found that could influence the abundance of seabirds by providing discards.

All seabirds and marine mammals were included in the censuses, but the great-winged petrel Pterodroma macroptera and the Leach's storm petrel Oceanodroma leucorhoa were particularly widespread and abundant over deeper ocean waters. Apart from being common and frequently encountered, there were frequent interactions between these two seemingly unrelated species, originating from breeding grounds in the Southern and the Northern Hemispheres, respectively (Brooke 2004). Frequent aerial displays (social interactions), the tendency to "huddle" in mixed flocks and frequent interactions during foraging and feeding were aspects that drew attention. These interactions inspired a detailed study of their behaviour and whereabouts at sea and an investigation of both the differences and similarities in behavioural aspects in relation to overall distribution, specific habitat characteristics and feeding opportunities of these two species at sea.

\section{Material, study area and methods}

Systematic seabird surveys were conducted 15-26 February 2000 and 29 January-11 February 2001 from Walvisbaai (Namibia) to Cape Town (South Africa) via the Walvis Ridge and 13 February-3 March 2001 to the SW of Cape Town, between 32 and $39^{\circ} \mathrm{S}$ latitude and 18 and $8{ }^{\circ} \mathrm{E}$ longitude (Figs. 1, 2).

Methods of observation, using strip-transect techniques, were similar to standards developed for ship-based seabird surveys in northwest European waters (Tasker et al. 1984), but with extra attention to and systematic coding of (foraging) behaviour and interactions between species (Camphuysen and Van der Meer 2001; Camphuysen and Garthe 2004). Following Tasker et al. (1984), a 300-m-wide transect was operated on one side and in front of the vessel, including a snap-shot count for flying birds and using 10min period intervals $(3.0 \pm 0.5 \mathrm{~km}$ linear distance per count $\times 0.3 \mathrm{~km}$ strip width), from which densities could be calculated $\left(n \mathrm{~km}^{-2}\right)$. Within the $300-\mathrm{m}$ transect, birds on the water (including storm petrels just touching the water!) were categorised to one of five different divisions, depending on distance perpendicular to the ship $(0-50,50$ $100,100-200,200-300 \mathrm{~m}$ and beyond $300 \mathrm{~m}$ or outside transect). Distances were judged by eye with regular verification using a hand-held range finder (Heinemann 1981). Simultaneously, a $180^{\circ}$ scan ahead of the ship was performed, providing a larger sample. Scan data, not used to calculate densities, but only for numbers of birds per km travelled $\left(n \mathrm{~km}^{-1}\right)$, are considered more accurate for the relative abundance of rarer birds, marine mammals and the occurrence of feeding frenzies. In 43 days, a total of $5,771 \mathrm{~km}$ was surveyed, covering approximately $1,702 \mathrm{~km}^{2}$ (Table 1). Means are \pm 1 standard deviation (SD), unless otherwise stated.

The analysis includes sightings of great-winged petrels and Leach's storm petrels only. Seabirds that followed the ship during steaming were recorded as "ship-associated during transects" (by default excluded from transect data that are used to calculate densities). Birds that approached the ship during steaming transects were considered "shipassociates" as well and treated accordingly whenever possible, to avoid the artificial inflation of calculated densities based on these transect counts. Estimates of total abundance in particular sea areas were made after correction of the data, taking differences in detection probability into account. To account for variations in detection of birds on the water (including dipping and pattering storm petrels) at different distances from the ship, the numbers of these birds were multiplied by a factor according to species and the width of the strip transect. The factors were calculated by comparing the numbers of 
Fig. 1 Records of great-winged petrels $\left(n \mathrm{~km}^{-1}\right)$ off southern Africa, January-March 2000 and 2001. The map also shows depth contours and five subregions used for this project: (1) Namibian Continental Shelf waters (coastal waters immediately adjacent to the mainland, up to a depth of $2,000 \mathrm{~m}$, north of $\left.27^{\circ} \mathrm{S}\right),(2)$ Cape Continental Shelf waters (ibidem, south of $32^{\circ} \mathrm{S}$ ), (3)deep ocean waters, between the shelf break (at 2,000 m depth) up to the (4) Walvis Ridge area (2,000-3,700-m depth), and separated from (5) the Agulhas ring area (an area with recently shed Agulhas rings), which was generally to the south of $35^{\circ} \mathrm{S}$ (dashed horizontal line)

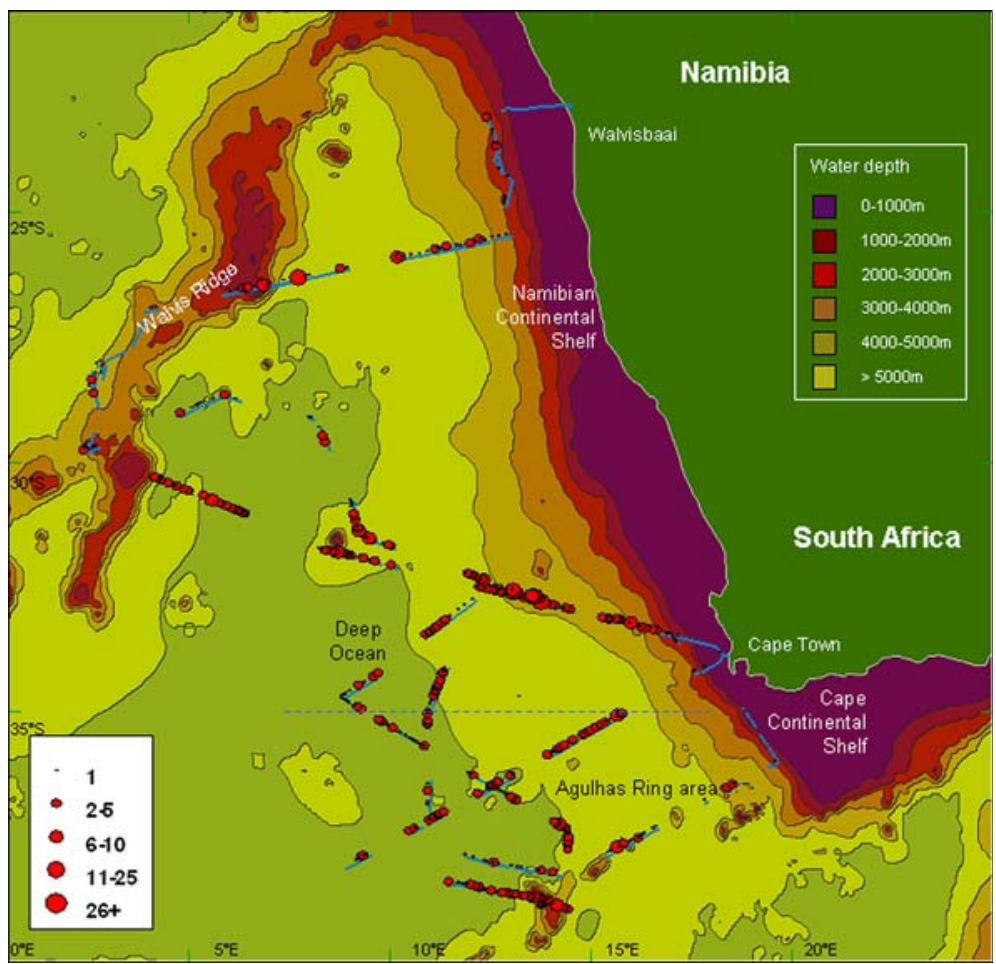

Fig. 2 Records of Leach's storm petrels $\left(n \mathrm{~km}^{-1}\right)$ off southern Africa, January-March 2000 and 2001. See for conventions Fig. 1

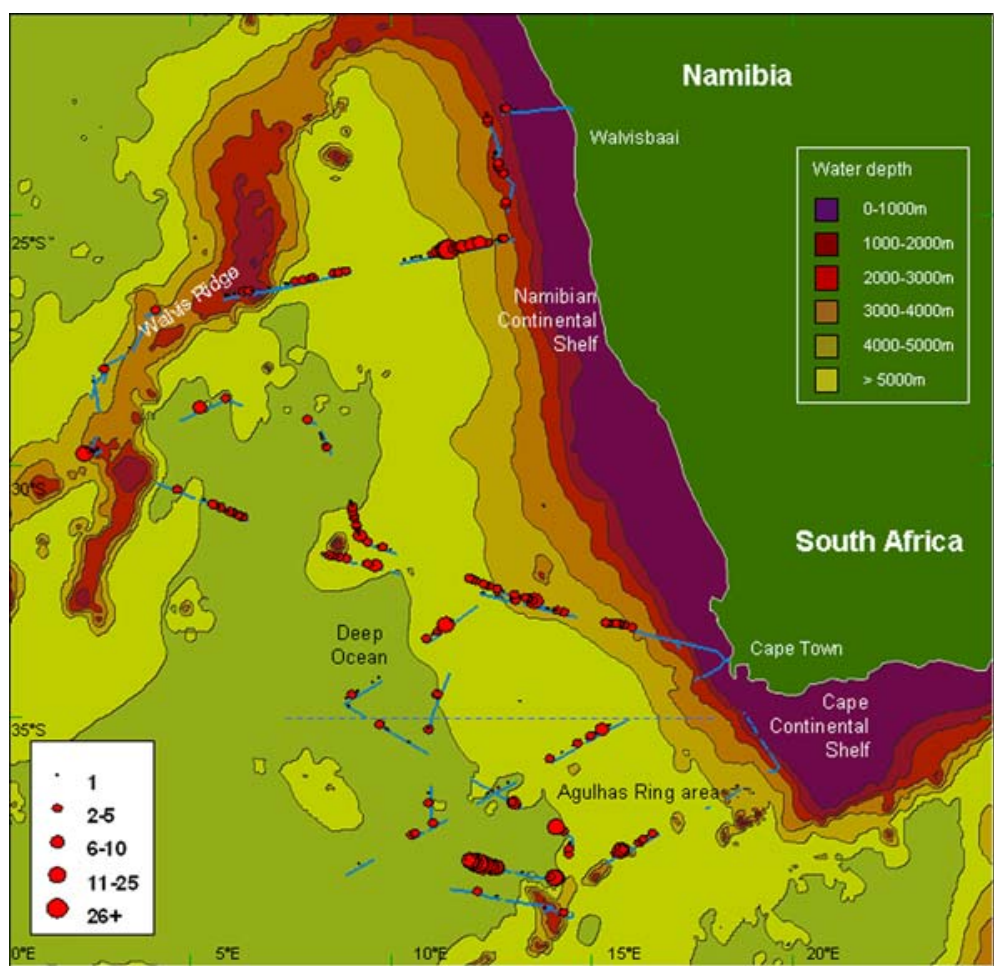

each species seen at different distances from the ship. Birds allocated to one of the four distance bands within the transect were examined on the assumption that the ratio of the totals would equal the ratio of the band widths (Buckland 1985; Stone et al. 1995).
The weather during the surveys varied, with counts being discontinued in stormy weather. With sea state coded from 0 (flat calm, sea as a mirror) to 6 (rough seas, crests break, foam streaks), the observer effort under each of these conditions was: $12.8 \mathrm{~h}$ with sea state 0 (4\% of the 
Table 1 Observer effort (number of 10-min counts, $\mathrm{km}^{2}$ surveyed and km travelled) in Feb 2000 and Jan-Mar 2001 (see Fig. 1 for subregions)

\begin{tabular}{llrr}
\hline Subregion & $\begin{array}{l}\text { Counts } \\
(n)\end{array}$ & \multicolumn{1}{c}{$\begin{array}{l}\text { Area } \\
\left(\mathrm{km}^{2}\right)\end{array}$} & \multicolumn{1}{c}{$\begin{array}{l}\text { Distance } \\
(\mathrm{km})\end{array}$} \\
\hline 2000 & & & \\
$\quad \begin{array}{l}\text { Namibian continental } \\
\quad \text { shelf }\end{array}$ & 137 & 104.0 & 346.6 \\
Deep ocean & 413 & 352.2 & $1,173.9$ \\
Walvis Ridge & 52 & 50.5 & 168.5 \\
Cape continental shelf & 27 & 24.4 & 81.3 \\
2001 & & & \\
Namibian continental & 76 & 57.7 & 192.4 \\
$\quad$ shelf & & & \\
Deep ocean & 464 & 405.4 & $1,422.1$ \\
Walvis Ridge & 113 & 108.5 & 360.8 \\
Cape continental shelf & 132 & 118.4 & 394.7 \\
Agulhas ring area & 550 & 481.1 & $1,630.5$ \\
& 1,964 & $1,702.2$ & $5,770.7$ \\
\hline
\end{tabular}

time), $27.9 \mathrm{~h}$ with sea state $1(8.5 \%), 45.8 \mathrm{~h}$ with sea state $2(14 \%), 65.8 \mathrm{~h}$ with sea state $3(20 \%), 68 \mathrm{~h}$ with sea state $4(20.5 \%), 87.8 \mathrm{~h}$ with sea state $5(27 \%)$ and $19.2 \mathrm{~h}$ with sea state $6(6 \%)$.

\section{Habitats}

The oceanographic research under MARE enabled studies of marine wildlife to investigate and interpret interactions with physical processes simultaneously. The study area was subdivided into five subregions (Figs.1, 2). Two of these were continental shelf waters, coastal waters immediately adjacent to the mainland, up to a depth of $2,000 \mathrm{~m}$. The (1) Namibian continental shelf waters (north of $27^{\circ} \mathrm{S}$ ) were separated from (2) Cape continental chelf waters (south of $32^{\circ} \mathrm{S}$ ), because a large area between the two was not investigated. (3) Deep ocean waters were between the shelf break (at 2,000 m depth) up to the (4) Walvis Ridge area (2,000-3,700 $\mathrm{m}$ depth), and these were further separated from (5) the Agulhas current retroflection region, in short, the Agulhas ring area, an area with recently shed Agulhas rings with a clear "surface signature", which was generally to the south of $35^{\circ} \mathrm{S}$ (Duncan 1968; Gordon 1985). Agulhas rings were characterised by a relatively high surface salinity and their anti-clockwise rotating velocity, and could be found and best followed by altimetry from a satellite (Sea Surface Height Anomaly Analysis from the Colorado Center for Astrodynamics Research; Wakker et al. 1990; Goni et al. 1997; van Veldhoven 2005).
These data, in combination with continuous recordings of surface salinity $(\%)$, surface temperature $\left({ }^{\circ} \mathrm{C}\right)$ and water depth (m; analysed at $500 \mathrm{~m}$ intervals), measured at 1-min intervals and automatically logged on board the ship, were used to describe and classify habitats at sea in broad terms. Shifts of surface salinity within 10 min transects of $\geq 0.1 \%$ were categorised as steep salinity gradients $(2.9 \%$, $n=1,96410$-min counts), shifts of $0.05-0.1 \%$ as medium gradients $(8.9 \%)$ and shifts $<0.05 \%$ as (near) stable situations $(88.2 \%)$ (similar to a method proposed by Haney and McGillivray 1985). Similarly, sea surface temperature shifts within individual transects of $>0.2^{\circ} \mathrm{C}$ were considered strong temperature gradients $(10.0 \%), 0.1>0.2^{\circ} \mathrm{C}$ as medium gradients $(16.1 \%)$ and $<0.1{ }^{\circ} \mathrm{C}$ as (near) stable situations $(73.9 \%)$. Steep salinity gradients were encountered most frequently in the Agulhas ring area $(5.6 \%$, $n=550)$ and on the Cape continental shelf $(8.2 \%, n=159$; Table 2). Steep temperature gradients were relatively frequently encountered at the Namibian continental shelf (14.6\%, $n=213)$, in the Agulhas ring area $(10.2 \%$, $n=550)$ and particularly at the Cape continental shelf (42.1\%, $n=159$; Table 2). Observed numbers of petrels in each situation were compared with expectation based on the frequency of encountered gradients ( $G$-test with Williams's correction; Sokal and Rohlf 1995).

\section{Behavioural observations and feeding associations}

Foraging behaviour, feeding success and certain types of non-foraging behaviour (e.g., resting/sleeping, preening, social display) were recorded as standard practice during transect counts (Camphuysen and Garthe 2004). Mixed (multi-species) flocks were carefully described in an attempt to document the various interactions between species, including notes on the type of interaction (aggressive or non-aggressive, food-related or not). The methods of recording developed during the surveys and notes made in 2001 are certainly more complete, comprehensive and systematic than those in 2000 , simply because the attention had first to become focussed on the interactions of these two widespread species. From field notes, the behaviour was grouped into four main categories as follows:

1. No particular behaviour (just flying or swimming)

2. Foraging and feeding

(a) natural behaviour, solitary or in mono- or multispecies flocks

(b) fishing vessel influenced

3. Resting at sea

(a) solitary, sleeping or preening

(b) huddling in mono- or multi-species gatherings 
Table 2 Occurrence of steep, moderate and shallow sea surface salinity and temperature gradients [frequency $(n)$ and \% of all 10-min counts surveyed in each subregion]

\begin{tabular}{|c|c|c|c|c|c|c|}
\hline & \multicolumn{3}{|c|}{ Salinity gradients } & \multicolumn{3}{|c|}{ Temperature gradients } \\
\hline & $\begin{array}{l}\geq 0.099 \% \\
\text { (steep) }\end{array}$ & $\begin{array}{l}\geq 0.049-0.098 \% \\
\text { (moderate) }\end{array}$ & $\begin{array}{l}<0.049 \% \\
\text { (shallow) }\end{array}$ & $\begin{array}{l}\geq 0.2^{\circ} \mathrm{C} \\
\text { (steep) }\end{array}$ & $\begin{array}{l}0.10-0.19^{\circ} \mathrm{C} \\
\text { (moderate) }\end{array}$ & $\begin{array}{l}<0.1^{\circ} \mathrm{C} \\
\text { (shallow) }\end{array}$ \\
\hline Namibian shelf & 0 & 3 & 210 & 31 & 64 & 118 \\
\hline$\%$ & 0.0 & 1.4 & 98.6 & 14.6 & 30.0 & 55.4 \\
\hline Walvis Ridge & 5 & 19 & 141 & 12 & 28 & 125 \\
\hline$\%$ & 3.0 & 11.5 & 85.5 & 7.3 & 17.0 & 75.8 \\
\hline Deep ocean & 8 & 54 & 815 & 31 & 72 & 774 \\
\hline$\%$ & 0.9 & 6.2 & 92.9 & 3.5 & 8.2 & 88.3 \\
\hline Agulhas ring area & 31 & 60 & 459 & 56 & 125 & 369 \\
\hline$\%$ & 5.6 & 10.9 & 83.5 & 10.2 & 22.7 & 67.1 \\
\hline Cape shelf & 13 & 38 & 108 & 67 & 27 & 65 \\
\hline$\%$ & 8.2 & 23.9 & 67.9 & 42.1 & 17.0 & 40.9 \\
\hline Totals & 57 & 174 & 1,733 & 197 & 316 & 1,451 \\
\hline$\%$ & 2.9 & 8.9 & 88.2 & 10.0 & 16.1 & 73.9 \\
\hline
\end{tabular}

4. Social display, aerial display

(a) individual displays

(b) mono-specific, group displays (pairs and larger aggregations)

(c) multi-specific, group displays

Listing behaviour as "searching for prey" as opposed to "just flying" is perhaps tricky in petrels, which may opportunistically search for prey whenever on the wing. However, in line with Veit (1999), the former referred to circling petrels focusing on some sea area, whereas birds in flight following a more or less straight course were labelled as "just flying". Species-specific differences in attraction to the research vessel were compared by calculating the total number of individuals seen versus the proportion seen during steaming, visibly attracted by the ship.

\section{Results}

\section{Distribition}

Great-winged petrels were observed in all areas (Fig. 1), but with relatively high densities (deep ocean $0.26 \mathrm{~km}^{-2}$;
Agulhas ring area $0.23 \mathrm{~km}^{-2}$ ) and high frequencies (35.7\% of all 87710 -min counts and $44.5 \%$ of all 550 counts) over deeper waters (Table 3). Positive records comprised relatively small numbers $(1.88 \pm 1.85$ individuals per 10 -min count, $n=606$ records, 1,139 individuals) and included aggregations up to 25 individuals. Leach's storm petrels occurred in all areas except over the Cape Town shelf (Fig. 2), with relatively high densities (deep ocean $0.44 \mathrm{~km}^{-2}$; Agulhas ring area $0.57 \mathrm{~km}^{-2}$ ) and high frequencies (35.7\% of all 877, 10-min counts and $44.5 \%$ of all 550 counts) over deeper waters (Table 2). Records comprised $3.01 \pm 4.73$ individuals per 10 -min count $(n=333$ records, 1,002 individuals) and included aggregations of up to 41 individuals. With comparatively large flocks in the core areas, frequencies of Leach's petrels $(23.9 \%$ of all 877,10 -min counts in deep ocean waters and $16.0 \%$ of all 550 counts in the Agulhas ring area) were considerably lower than in great-winged petrels (Table 3). In deep ocean waters and the Agulhas ring area, numbers of great-winged petrels seen were significantly larger during 10-min counts where both species were present $(2.6 \pm 3.0$ individuals per count, $n=193$ records, 497 individuals) than during counts where Leach's storm petrels did not occur

Table 3 Presence (\% as a fraction of all 10-min counts), densities $\left(n \mathrm{~km}^{-2}\right)$, total number of individuals per km travelled of great-winged petrels and Leach's storm petrels in either area (2000 and 2001 data combined)

\begin{tabular}{|c|c|c|c|c|c|c|}
\hline \multirow[t]{2}{*}{ Subregion } & \multicolumn{3}{|c|}{ Great-winged petrel } & \multicolumn{3}{|c|}{ Leach's storm petrel } \\
\hline & $\begin{array}{l}\text { Presence } \\
(\%)\end{array}$ & $\begin{array}{l}\text { Density } \\
\left(n \mathrm{~km}^{-2}\right)\end{array}$ & $\begin{array}{l}\text { N per km steamed } \\
\left(n \mathrm{~km}^{-1}\right)\end{array}$ & $\begin{array}{l}\text { Presence } \\
(\%)\end{array}$ & $\begin{array}{l}\text { Density } \\
\left(n \mathrm{~km}^{-2}\right)\end{array}$ & $\begin{array}{l}\mathrm{N} \text { per } \mathrm{km} \text { steamed } \\
\left(n \mathrm{~km}^{-1}\right)\end{array}$ \\
\hline Namibian continental shelf & 6.1 & 0.02 & 0.03 & 11.3 & 0.10 & 0.07 \\
\hline Walvis Ridge & 11.5 & 0.04 & 0.04 & 6.7 & 0.05 & 0.05 \\
\hline Deep ocean & 35.7 & 0.26 & 0.24 & 23.9 & 0.44 & 0.20 \\
\hline Agulhas ring area & 44.5 & 0.23 & 0.28 & 16.0 & 0.57 & 0.25 \\
\hline Cape continental shelf & 10.1 & 0.04 & 0.04 & 0 & 0.0 & 0.0 \\
\hline
\end{tabular}


(1.8 \pm 1.7 individuals per 10 -min count, $n=459$ records, 811 individuals; $\left.z_{192,458}=3.50, P<0.01\right)$. Numbers of Leach's storm petrels were similar to or without greatwinged petrels $(2.91 \pm 4.54$ individuals per count, $n=193$ records, 561 individuals and $2.22 \pm 3.64, n=215$ records, 477 individuals, respectively; $z_{192,214}=1.68, \mathrm{~ns}$ ).

\section{Hydrographical features}

The relative abundance of both species peaked at depth, and this pattern was most pronounced in Leach's storm petrels (Fig. 3). Geat-winged petrels and Leach's storm petrels showed an association with meso-scale hydrographic features expressed as positive and negative sea surface height anomalies. The latter species was more patchily distributed, but both species were comparatively common at the edges of these anomalies or at the interface between positive (anti-cyclones or Agulhas rings) and negative (cyclones) anomalies (Fig. 4). The central areas of the Agulhas rings in particular were virtually devoid of visible marine life at the sea surface. Looking in more detail at the data, Leach's storm petrels were found in significantly higher numbers than expected in deep water areas with steep sea surface salinity and/or temperature gradients. By far the highest densities occurred in areas with steep salinity gradients combined with steep to moderate sea surface temperature gradients $(4.2-5.6 \times$ background densities of $0.49 \mathrm{~km}^{-2}$; Table 4). No such tendency was found in great-winged petrels. Strong gradients were sometimes visible at the surface as streaks on the water or foam lines with flotsam, indicating the presence of fronts, but on numerous occasions, nothing that was measured at the water surface was visible to the human eye. Strong gradients were frequently encountered at the interface between positive and negative anomalies in the Agulhas ring area. Strong gradients at the shelf and shelf break were

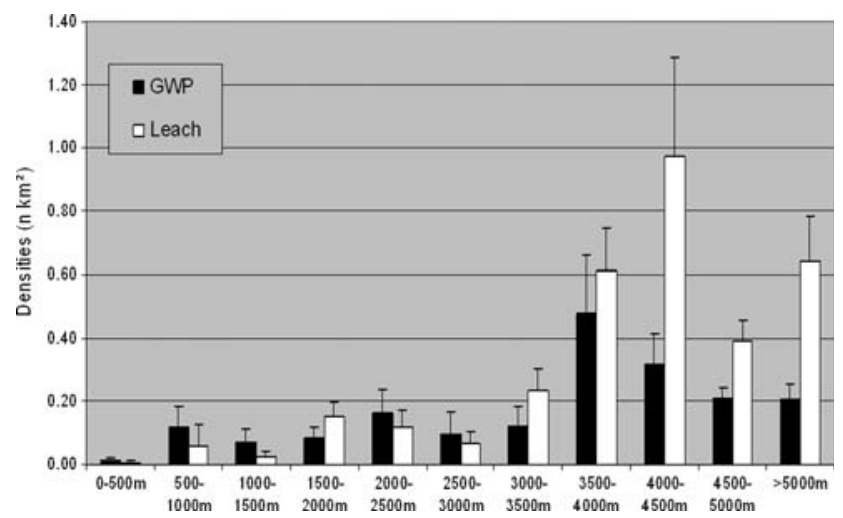

Fig. 3 Relative abundance $\left(n \mathrm{~km}^{-2} \pm \mathrm{SE}\right)$ of great-winged petrels and Leach's storm petrels with water depth utilised by numerous storm petrels, but not (or rarely) Leach's.

Foraging and feeding

Of 1,139 great-winged petrels recorded, $10.3 \%$ were engaged in foraging or feeding activities (Table 5). Of the 117 apparently feeding petrels, $51(43.6 \%)$ were associated with Leach's storm petrels, three $(2.6 \%)$ with cetaceans, one $(0.9 \%)$ with another seabird (Cory's shearwater Calonectris borealis), five birds $(4.3 \%)$ at a trawler and the remaining birds alone or with conspecifics $(48.7 \%)$. There were numerous observations of great-winged petrels actively joining foraging Leach's storm petrels and none of the reverse, suggesting that the former species profited from the searching efficiency of the latter. Three aggressive encounters were observed where great-winged petrels attempted to get prey found by Leach's storm petrels $(2 \times$ unsuccessful or abandoned, $1 \times$ successful). The Cory's shearwater (handling prey) was approached, but not attacked. Defence behaviour against a conspecific was observed by one surface seizing pair of birds (raised wings; large, unidentified prey). Of 1,002 Leach's storm petrels recorded, $66.2 \%$ were engaged in foraging or feeding activities (Table 5). In all, 579 individuals were foraging or feeding alone, with no other seabirds interested. Some 55 foraging individuals $(8.3 \%$ of all foraging Leach's storm petrels observed) were joined by great-winged petrels. Another 28 individuals (4.2\%) were joined by other seabirds, including Cory's shearwater, sooty shearwater Puffinus griseus, black-browed albatross Thalassarche melanophrys and spectacled petrel Procellaria conspicillata. On five occasions, ship-following seabirds left the vessel to join a small flock of feeding storm petrels encountered ahead of the vessel. One Leach's storm petrel was successful in pecking up small morsels of prey falling off a large fish handled by a Cory's shearwater. The same happened when a storm petrel was driven away from a large prey by a great-winged petrel, and the intake rate of the storm petrel apparently increased when the larger predator started to tear apart the large prey.

At the Namibian and Cape shelf areas combined, active fishing vessels occurred within view for $17.3 \%$ of the survey time and $3.9 \%$ of that time these vessels were nearby (Table 6). No fishing activity was encountered in the Walvis Ridge area, whereas over deep waters, fishing vessels were within view of no more than $1.1 \%$ of the time ( $0.3 \%$ nearby). Nearby fishing vessels in the Agulhas ring area resulted in substantially higher abundances of both great-winged petrels $\left(0.50\right.$ rather than $\left.0.28 \mathrm{~km}^{-1}\right)$ and Leach's storm petrels (2.28 rather than $0.23 \mathrm{~km}^{-1}$ ), indicating an attraction of these vessels for both species, or convergence in productive areas (Table 6). Only one 
Fig. 4 Relationships between the distribution of a greatwinged petrels and b Leach's storm petrels and meso-scale hydrographic features in the Agulhas current retroflection region. The map shows seasurface height anomalies $(\mathrm{m})$ composed of TOPEX/Poseidon and ERS 2 satellite altimetry data for the period 13-28 February 2001, showing the situation during the MARE (-4) cruise. The -0.2 and $0.2 \mathrm{~m} \mathrm{SSH}$ anomaly contours have been drawn. The black arrows show the observed velocity vectors from LADCP measurements (lowered acoustic Doppler current profiler) over the top $500 \mathrm{~m}$, after Veldhoven A van (2005). The dots show relative abundances of petrels over the tracklines (black), as in Figs. 2 and 3. Depth contours include the 2,000- and 5,000-m depth intervals. Agulhas ring

"Astrid" is indicated by a capital A
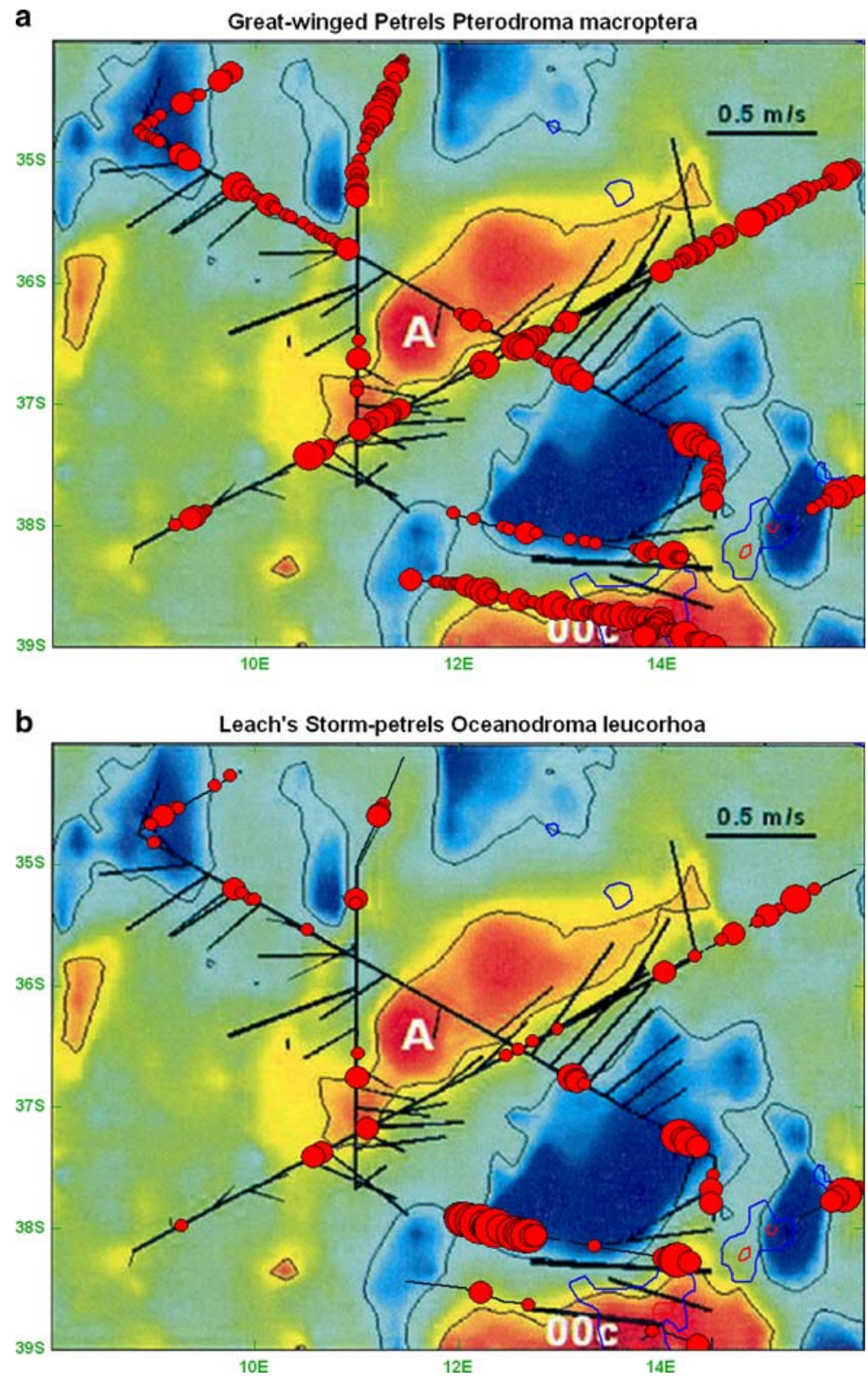

Leach's storm petrel was observed searching for prey in the immediate vicinity of a fishing vessel (15 February 2000, $23^{\circ} \mathrm{S}, 13^{\circ} \mathrm{E}$, freezer trawler, Namibian shelf), while five great-winged petrels were seen scavenging on another occasion (27 February $2001,38^{\circ} \mathrm{S}, 14^{\circ} \mathrm{E}$, long-liner, Agulhas ring area).

\section{Other behaviour}

Some $61.6 \%$ of all great-winged petrels recorded were logged as flying past, with another $2.9 \%$ as swimming ( $n=1,139$; Table 5 ). The remaining non-feeding individuals were either preening, resting or engaged in aerial displays. Flight was in all directions, with no indication for directed movements anywhere, anytime. At least 29 indi- viduals were associated with the research vessel $(2.5 \%$, $n=1,139)$. Some $10.3 \%$ of all Leach's storm petrels recorded were logged as flying past $(n=1,002$; Table 5). The remaining non-feeding individuals were preening, resting or engaged in aerial displays. At least 16 individuals were associated with the research vessel $(1.5 \%$, $n=1,002$ ).

\section{Huddling behaviour}

While multi-species feeding associations between greatwinged petrels and Leach's storm petrels occurred both frequently and understandably (see above), close interactions on numerous other occasions came as a surprise. Apart from 38 great-winged petrels and 35 Leach's storm 
Table 4 Associations of great-winged petrels and Leach's storm petrels with sea surface salinity and temperature gradients in deep ocean waters and in the Agulhas ring area (2000 and 2001 data combined)

\begin{tabular}{|c|c|c|c|c|c|c|c|c|c|}
\hline & \multirow[t]{2}{*}{ Counts } & & \multicolumn{4}{|c|}{ Great-winged petrel } & \multicolumn{3}{|c|}{ Leach's storm petrel } \\
\hline & & & \multicolumn{2}{|l|}{ Observed } & \multicolumn{2}{|l|}{ Expected } & Counts & Observed & Expected \\
\hline \multicolumn{10}{|c|}{ Salinity gradients $(\%)$} \\
\hline$\geq 0.099$ & 37 & \multicolumn{3}{|c|}{5} & \multicolumn{2}{|c|}{9} & 37 & 75 & 18 \\
\hline$\geq 0.049-0.098$ & 104 & \multicolumn{3}{|c|}{18} & 26 & & 104 & 54 & 51 \\
\hline$<0.049$ & 1,098 & \multicolumn{3}{|c|}{285} & 273 & & 1,098 & 480 & 540 \\
\hline$G_{\text {adj }}$ & & \multicolumn{3}{|c|}{2.8} & \multicolumn{2}{|l|}{$\mathrm{ns}$} & & 40.8 & $P<0.001$ \\
\hline \multicolumn{10}{|c|}{ Temperature gradients $\left({ }^{\circ} \mathrm{C}\right)$} \\
\hline$\geq 0.2$ & 78 & \multicolumn{3}{|c|}{12} & \multicolumn{2}{|c|}{19} & 78 & 74 & 39 \\
\hline$\geq 0.1$ & 174 & \multicolumn{3}{|c|}{38} & 43 & & 174 & 161 & 86 \\
\hline$<0.1$ & 986 & \multicolumn{3}{|c|}{258} & 245 & & 986 & 374 & 485 \\
\hline$G_{\text {adj }}$ & & \multicolumn{3}{|c|}{2.4} & ns & & & 49.0 & $P<0.001$ \\
\hline \multirow{2}{*}{\multicolumn{2}{|c|}{ Salinity/temperature gradients }} & \multicolumn{5}{|c|}{ Great-winged petrel } & \multicolumn{3}{|c|}{ Leach's storm petrel } \\
\hline & & \multicolumn{2}{|l|}{$\geq 0.2^{\circ} \mathrm{C}$} & \multicolumn{2}{|l|}{$0.1-0.19^{\circ} \mathrm{C}$} & $<0.1^{\circ} \mathrm{C}$ & $\geq 0.2^{\circ} \mathrm{C}$ & $0.10-0.19^{\circ} \mathrm{C}$ & $<0.1^{\circ} \mathrm{C}$ \\
\hline \multicolumn{2}{|l|}{$\geq 0.099 \%$} & \multicolumn{2}{|l|}{0.08} & \multicolumn{2}{|l|}{0.31} & 0.27 & 2.08 & 2.76 & 0.53 \\
\hline \multicolumn{2}{|l|}{$\geq 0.049-0.098 \%$} & 0.35 & & 0.16 & & 0.06 & 0.49 & 0.81 & 0.09 \\
\hline$<0.049 \%$ о & & 0.07 & & 0.24 & & 0.27 & 0.27 & 0.87 & 0.39 \\
\hline Overall mean de & & 0.25 & & & & & 0.49 & & \\
\hline
\end{tabular}

Expectations were based on observer effort, assuming random distribution. The bottom half of the table provides densities $\left(n \mathrm{~km}^{-2}\right)$ observed in each of the salinity/temperature gradient combination and the overall (background) density in the entire area

petrels encountered asleep (and a further two great-winged petrels bathing and preening), 128 great-winged petrels (33 records, maximum involving 17 individuals) and 100 Leach's storm petrels (30 records, maximum 23 individuals) were encountered while "'huddling together' in tight gatherings. Of these, 11 gatherings contained only a single species $(7 \times$ great-winged petrel, $\max 8 ; 4 \times$ Leach's storm petrel, max 23), but no less than 25 gatherings contained both species and a further gathering was found to also involve a Bulwer's petrel Bulweria bulwerii (mean flocksize $6.2 \pm 5.5$ individuals $(n=25)$; maximum number of individuals in one gathering: 17 great-winged petrels and 9 Leach's storm petrels). Loose gatherings were flocks where some water remained visible between individuals that were swimming close together. Huddling packs, however, were extremely tight flocks of birds, from a distance looking as a single black "blob" that had to take wing before a count or even identification was at all possible. Such gatherings were typically "exploding', into all possible directions when approached, and participating birds would either fly off, commence feeding (dipping) or searching, and/or were promptly engaged into various aerial displays. Mono- and multi-species gatherings occurred most often in very deep waters (>3,500-m depth). With 1,161 great-winged petrels observed in areas with known water depth, 930 individuals occurred in waters over 3,500-m depth. Of these, $13.4 \%$ occurred in gatherings as described. In shallower waters, only $1.5 \%$ of the petrels were seen to huddle $(n=202)$, a significantly smaller proportion than expected from overall numbers in either area $\left(G_{\mathrm{adj}}=28.61, P<0.001\right)$. Similar values were reached for Leach's storm petrels, with $11.3 \%$ huddling in waters over 3,500-m depth $(n=869)$ and only $1.6 \%$ in shallower waters $\left(n=127 ; G_{\text {adj }}=14.19\right.$, $P<0.01)$. Gatherings in both species were exclusively seen in the deep ocean and Agulhas ring areas.

Aerial displays

Aerial displays were frequently observed in both species (Table 5), and the performances came in a variety of forms and intensities, either involving a solitary bird, a pair of birds, a flock of birds, but one species, or even flocks of birds including both species. Both species performed aerial displays with wing beats reminiscent of butterflies. These displays were most common in Leach's petrels (60 records) and involved pairs as well as solitary birds. Great-winged petrels were often found circling in areas, sometimes in flocks, but without a tendency to focus on a particular part of the sea surface and interrupted by aerial displays in various forms. Circling Procellariiforms are generally assumed to be searching (hence, foraging) birds (Veit 1999), but on the described occasions, the attitude of the birds 
Table 5 Behaviour of greatwinged petrels and Leach's storm petrels observed

\begin{tabular}{|c|c|c|}
\hline Behaviour type & Great-winged petrel & Leach's storm petrel \\
\hline \multicolumn{3}{|l|}{ No particular behaviour } \\
\hline In flight & 702 & 104 \\
\hline Swimming & 34 & 23 \\
\hline \multicolumn{3}{|l|}{ Foraging behaviour } \\
\hline Aerial pursuit & 2 & \\
\hline Scavenging at fishing vessel & 5 & \\
\hline Dipping and pattering & & 454 \\
\hline Surface seizing & 5 & 17 \\
\hline Actively searching & 105 & 192 \\
\hline \multicolumn{3}{|l|}{ Huddling on the water, preening or resting } \\
\hline Huddling, mono-species, tight flock & 34 & 36 \\
\hline Huddling, multi-species, tight flock & 94 & 64 \\
\hline Resting or apparently asleep & 38 & 35 \\
\hline Preening or bathing & 2 & \\
\hline \multicolumn{3}{|l|}{ Display behaviour } \\
\hline Aerial display, not specified & 15 & 4 \\
\hline Aerial display, 8-pattern or O-pattern trajectories & 14 & \\
\hline Aerial display, as fighting blackbirds & & 2 \\
\hline Aerial display, strange wingbeats and towering flight & 56 & 67 \\
\hline Aerial display, tandem-flight, simultaneous & 28 & 4 \\
\hline Social display, aggressive towards other passive individual & 5 & \\
\hline Total number of birds observed & 1,139 & 1,002 \\
\hline No particular behaviour & $64.6 \%$ & $12.7 \%$ \\
\hline Foraging behaviour & $10.3 \%$ & $66.2 \%$ \\
\hline Huddling on the water, preening or resting & $14.7 \%$ & $13.5 \%$ \\
\hline Display behaviour & $10.4 \%$ & $7.7 \%$ \\
\hline
\end{tabular}

seemed different. Sometimes circles would give way for 8shaped trajectories, with sudden outbursts of spectacular wing beats, accelerations and towering flights. Bouts of quick wing-beats could be alternated with bouts of strange, slow wing beats with stiff wings (slow-motion flight) and often peculiar postures of the head, reminiscent of all sorts of other birds, including skimmers, swifts or raptors. Tandem flights were most common in great-winged petrels, but have been seen in Leach's petrels also. On such occasions, two individuals would follow each other at very short distance, with identical wing-beats and body postures and following the same route (perhaps the following bird imitating the leader). One particular display involved Leach's storm petrels and this was described as "fighting male blackbirds"': very quick flight of two birds, approaching and leaving each other irregularly (sometimes in physical contact as a flurry of black feathers) following a chaotic zig-zag course. Several displaying great-winged petrels seemed to irritate conspecifics and the result was a brief fight or a chase, ending the display. Variations were endless and there is no point trying to describe all the variations observed. Example are: a tight gathering of six great-winged petrels, one Bulwer's petrel and five Leach's petrels took off in all directions with six great-winged petrels promptly engaged in a whirling aerial display chasing each other. In another flock, two great-winged petrels and a single Leach's petrel swimming tightly took off, with the former species promptly engaged in a tandemdisplay, while the latter commenced feeding as if nothing had happened. It is interesting, however, that displaying birds did not just interact with conspecifics. The next example comprised a single great-winged petrel that performed the most spectacular, swift-like display following a wide, 8-shape trajectory around two swimming Leach's storm petrels that seemingly paid no attention. Displaying great-winged petrels around Leach's storm petrels were a common sight, and sometimes seemed to trigger outbursts of aerial displays in the smaller species also. Numerous other examples, variations on these themes, were seen.

\section{The effect of weather}

Selecting the key areas for both species (deep ocean and Agulhas ring areas), there was some influence of wind and weather on the behaviour observed. All behavioural aspects were seen in conditions ranging from completely still 
Table 6 Presence of fishing vessels during surveys (over $2 \mathrm{~km}$ recorded as distant, within $2 \mathrm{~km}$ recorded as nearby) and the relative abundance of greatwinged petrels and Leach's storm petrels (number of birds observed, number of birds per $\mathrm{km}$ steamed)

\begin{tabular}{|c|c|c|c|c|c|c|}
\hline & \multirow[t]{2}{*}{ km surveyed } & \multirow[t]{2}{*}{ Area } & \multicolumn{2}{|c|}{ Great-winged petrel } & \multicolumn{2}{|c|}{ Leach's storm petrel } \\
\hline & & & $n$ & $n(\mathrm{~km})$ & $n$ & $n(\mathrm{~km})$ \\
\hline \multicolumn{7}{|l|}{ Namibian shelf } \\
\hline No visible fishing vessel & 437 & 131 & 15 & 0.03 & 35 & 0.08 \\
\hline Distant fishing vessels & 79 & 24 & 0 & 0 & 3 & 0.04 \\
\hline Nearby fishing vessels & 24 & 7 & 0 & 0 & 1 & 0.04 \\
\hline \multicolumn{7}{|l|}{ Walvis Ridge } \\
\hline No visible fishing vessel & 529 & 159 & 22 & 0.04 & 25 & 0.05 \\
\hline \multicolumn{7}{|l|}{ Deep ocean } \\
\hline No visible fishing vessel & 2,582 & 753 & 631 & 0.24 & 532 & 0.21 \\
\hline Distant fishing vessels & 14 & 4 & 0 & 0 & 0 & 0 \\
\hline \multicolumn{7}{|l|}{ Agulhas ring area } \\
\hline No visible fishing vessel & 1,597 & 471 & 443 & 0.28 & 370 & 0.23 \\
\hline Distant fishing vessels & 20 & 6 & 2 & 0.10 & 4 & 0.20 \\
\hline Nearby fishing vessels & 14 & 4 & 7 & 0.50 & 32 & 2.28 \\
\hline \multicolumn{7}{|l|}{ Cape shelf } \\
\hline No visible fishing vessel & 402 & 121 & 15 & 0.04 & 0 & 0 \\
\hline Distant fishing vessels & 57 & 17 & 3 & 0.05 & 0 & 0 \\
\hline Nearby fishing vessels & 16 & 5 & 1 & 0.06 & 0 & 0 \\
\hline
\end{tabular}

weather (sea as a mirror, sea state $0-1$ ) to rough seas (sea state 5-6), in roughly similar proportions. However, significantly higher numbers of great-winged petrels were observed foraging or feeding in still weather than could be expected from the overall numbers seen $\left(G_{\text {adj }} 19.0, d f=3\right.$, $P<0.01$; Table 7). The tendency to huddle in tight gatherings increased with sea state in great-winged petrels $\left(R_{\mathrm{S}}\right.$ $0.77, n=6, P<0.05)$, but not in Leach's petrels $\left(R_{\mathrm{S}} 0.09\right.$, $n=6$, ns). Otherwise, the deviations from the overall picture were at best modest, suggesting minor influences of weather conditions on the behaviour of these pelagic seabirds.

\section{Discussion}

The principal breeding grounds of the Leach's storm petrel are found in the northwest Atlantic and northeast Pacific (Huntington et al. 1996), with the world's largest known colony on Baccalieu Island off Newfoundland (3.4 million pairs; Sklepkovych and Montevecchi 1989). Migratory movements take Atlantic birds southwards to their major wintering areas, thought to be off equatorial Brazil and west Africa (Cramp and Simmons 1977; Brooke 2004). In 1996, a small breeding colony was found on Dyer Island off the south coast of South Africa. This represents thus far the only confirmed breeding of this species in the southern hemisphere (Whittington et al. 1999; Underhill et al. 2002). In southern Africa, Leach's storm petrel is currently known as a summer visitor and rare breeder, "fairly common", off the west and south coasts and typically occurring in oceanic waters and over the shelf edge, but rare inshore (Ryan and Whittington 1997). The great-winged petrel, a southern hemisphere winter breeder, is chiefly present off southern Africa November-March. Great-winged petrels in the South Atlantic have the rather blackish face characteristic of the nominate race, breeding in the Tristan/Gough

Table 7 Behaviour and weather (based on sea state, ranging from still weather to rough seas) in the deep ocean and Agulhas ring areas, as the proportion of birds observed

\begin{tabular}{lllll}
\hline & \multicolumn{3}{l}{ Great-winged petrel } \\
\cline { 2 - 5 } Sea state: & $0-1$ & $2-4$ & $5-6$ & All birds \\
Description: & Still & Calm-moderate & Rough & \\
\hline No behaviour (\%) & 57.8 & 65.6 & 63.8 & 64.1 \\
Foraging (\%) & 30.2 & 8.5 & 6.8 & 10.2 \\
Resting (\%) & 5.2 & 12.0 & 22.8 & 15.5 \\
Display (\%) & 6.9 & 13.9 & 6.6 & 10.2 \\
$n=$ & 116 & 541 & 426 & 1,083 \\
\hline & & & & \\
Seach's storm petrel & & $5-6$ & All birds \\
Description: & $0-1$ & $2-4$ & Rough & \\
\hline No behaviour (\%) & 3.5 & 12.4 & 15.3 & 10.9 \\
Foraging (\%) & 76.2 & 63.5 & 62.7 & 67.1 \\
Resting (\%) & 11.2 & 13.1 & 17.7 & 14.4 \\
Display (\%) & 9.1 & 10.9 & 4.2 & 7.7 \\
$n=$ & 286 & 274 & 378 & 938 \\
\hline
\end{tabular}


Islands, Prince Edward Islands, Îles Crozet, Îles Kerguelen and islands of southwest Australia (Brooke 2004). Off southern Africa, it typically occurs in oceanic waters and over the shelf edge, but great-winged petrels may be seen from coastal promontories during strong onshore winds (Ryan 1997). The present study confirms the status of both species as oceanic birds, with rather lower densities over the Namibian and Cape shelf areas (Table 3, Fig. 3). For the first time, however, their offshore distribution could be mapped in considerable detail, using a platform of opportunity that did not attract the species as a fishing vessel might have done. It appeared that the deep ocean, beyond the shelf break, off southern Africa is not a trivial staging area for either species. Assuming surface areas of ca. $1,040,000 \mathrm{~km}^{2}$ for the deep ocean subregion, ca. $116,000 \mathrm{~km}^{2}$ for the Walvis Ridge area (together $24-35^{\circ} \mathrm{S}$, $3-15^{\circ} \mathrm{E}, 10 \%$ of which is labelled as "Walvis Ridge") and ca. $355,000 \mathrm{~km}^{2}$ for the Agulhas ring area $\left(35-39^{\circ} \mathrm{S}\right.$, $9-18^{\circ} \mathrm{E}$ ), petrel densities as shown in Table 3 , and correction factors of 1.53 for swimming great-winged petrels and 1.67 for all Leach's storm petrels in transect, the deeper waters off southern Africa might have held half a million great-winged petrels $(412,500$ in deep ocean, 7,000 in the Walvis Ridge area, and 125,000 in the Agulhas ring area) and well over a million Leach's storm petrels $(765,000,9,700$ and 335,000, respectively). These are rough estimates, assuming no significant attraction of the research vessel and without taking into account the relative area along fronts and eddies separately from the whole area, but are probably indicative for the right order of magnitude.

The foraging ecology of either species is very different. The nearly $600 \mathrm{~g}(460-745 \mathrm{~g})$ great-winged petrel is a specialised squid (Cephalopoda) feeder. Bioluminescent species among the prey caught suggest that the birds forage at night (Marchant and Higgins 1990; Brooke 2004). A division of the cephalopod component of stomach contents of petrels in the Benguela region into species that float or sink after death indicates that the birds forage on dead or moribund cephalopods on the surface, rather than catching live bioluminescent cephalopods at night, however (Lipinski and Jackson 1989). Squid comprised 64\% and crustaceans $32 \%$ of their food by mass at Crozet (Ridoux 1994). Marchant and Higgins (1990) reported 49 observations of feeding great-winged petrels, all at night, of which $55 \%$ were surface-seizing and $45 \%$ dipping. Dipping greatwinged petrels targeted crustaceans, and the birds were seen to rise into the air to consume them. The Leach's

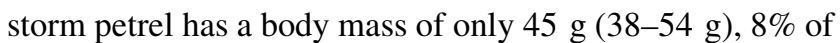
an average great-winged petrel, and their diet includes crustaceans, fish, small cephalopods and soft-bodied invertebrates, mostly picked up by surface sizing, dipping or pattering in flight (Prince and Morgan 1987). Biolumi- nescent Myctophids, prominent among the fish taken, hint at some nocturnal feeding (Huntington et al. 1996), but Leach's petrels are commonly seen feeding during the day. Note that there is no dietary information of non-breeding petrels of either species available. During the surveys reported here, very few great-winged petrels were foraging or feeding. Ignoring 105 foraging individuals that were $\log$ ged as "actively searching", only 12 birds (1\%) of the birds seen were actually handling prey. The fraction of birds foraging and feeding ( $10.1 \%$ in all) was similar in each of the areas surveyed. A radically different picture emerged in Leach's storm petrels. Setting aside the searching (i.e., foraging) individuals, still nearly $50 \%$ of the birds seen were actively feeding. Dipping was the dominant feeding mode, with a small proportion of the birds surface seizing (Table 5). Foraging and feeding was a prominent acitivity in any of the regions where Leach's Storm petrels occurred, but certainly so in the Agulhas ring area $(75.9 \%, n=406)$. These results support the suggestion that great-winged petrels are principally nocturnal feeders and indicate that Leach's storm petrels spend considerable time feeding in day time. The presence of fishing vessels had some effect on petrel densities in both species, but only over deep ocean waters. Several fishing vessels in shelf waters did not notably elevate densities recorded at sea (Table 6). For great-winged petrels, only a single sighting of scavenging individuals at a fishing vessel was obtained (five individuals), whereas Leach's storm petrels were foraging in the vicinity of these boats, possible focussing on fish oil or tiny scraps rather than on discards or offal in seabird feeding frenzies.

From the differences in foraging activity observed during daytime (when visual data have to be collected), it might be concluded that relationships between the distribution of the birds and hydrographic features characterising offshore habitats are more likely to be found in the Leach's storm petrels. Even although most great-winged petrels were active rather than resting during the day, their swift and easy flight could bring them far away from key nighttime feeding areas. Both species showed an association with meso-scale hydrographic features expressed as positive and negative sea surface height anomalies (sensu warm and cold eddies, Fig. 4), suggesting that these might contain elevated stocks of potential prey. It has recently been demonstrated that eddies spawned off the major frontal systems are rich in zooplankton/micronekton standing stock (Froneman et al. 1999). Multi-net plankton catches during the surveys revealed high concentrations of zooplankton in the interface between the Agulhas Rings and the cyclone areas (Frank Peeters pers. comm), confirming earlier observations. Nel et al. (2001) showed that grey-headed albatross Thalassarche chrysostoma were feeding at the edges of sea surface height anomalies, 
mostly on fish (Magnisudis prionosa) and squid (Martialia hyadesi), which were presumably attracted by the presence myctophids and crustaceans (e.g., decapod shrimps), in turn attracted by elevated stocks of copepods, amphipods and euphausiids, which were well represented in their samples. They proposed that crustaceans might be forced to move upward in decaying warm eddies in order to stay in their preferred environment, enhancing the foraging opportunities for surface feeding top predators. Physical processes that cause predictable near-surface aggregations of prey include boundary fronts, where water masses converge or diverge (Haney 1986a, b; Shealer 2002) and boundary fronts persisting around the Agulhas rings observed. Steep seas surface salinity and temperature gradients and strong currents (LADCP measurements, Fig. 4; Veldhoven A Van 2005) were indicative for these conditions and in particular Leach's storm petrels were clearly attracted.

Rather little has been published on the offshore distribution and at sea behaviour of either species. Enticott and Tipling (1997) described great-winged petrels as generally solitary, nocturnal feeders that may form gatherings at trawlers. Flight patterns have been described as "Impetuous, hurrying over ocean in high sweeping arcs" (Harrison 1987), and with "swift-like proportions and characteristic switchback flight, habitually towering high into sky in wild pendulum-motion progression" (Serventy et al. 1971; Harrison 1983). D.W. Eades (in Marchant and Higgins 1990) described the curious habit of following close behind, and flying in tandem with other dark Procellariiformes, e.g., northern giant petrel Macronectes halli, as if in display. Otherwise, there is no specific reference to aerial displays at sea in any of these publications. Aerial chases near colonies involve flocks from 2 to 12 birds, dashing at high speed accompanied by a "kik kik.." call (Elliot 1957; Marchant and Higgins 1990). Great-winged petrels observed off southern Africa were silent for as far as could be judged; even at close quarters, no calls could be heard. Flight patterns of Leach's storm petrels are described as buoyant and bounding with short shearwater-like glides on bowed wings with sudden, swift changes of speed and direction, weaving an irregular course between deep ternlike wing-beats and short shearing glides (Harrison 1983, 1987; Enticott and Tipling 1997). Again, there are no references to aerial displays at sea in the literature. It was clear that Leach's storm petrels performed well in all weather conditions, but with foraging slightly more prominent (or visible to the observer) in still weather (76.2\% of the birds observed, $n=286$ ) than in strong winds $(62.7 \%, n=378)$. Aerial displays and resting birds were seen in all conditions in roughly equal frequencies (Table 7). With the age of displaying petrels being unknown, it is speculative to categorise aerial displays ob- served as territorial, social or even courtship interactions. Many great-winged petrels operated in couples; it is not clear what the relation of the two birds might have been. When feeding during daytime would be a lower priority (nocturnal feeding habits), great-winged petrels could spend more time in display than Leach's storm petrels. In effect, however, the time spent displaying (expressed as the proportion of individuals seen in display) in either species was similar. The data are obviously inconclusive with respect to the nocturnal behaviour of Leach's storm petrels at sea. It is of interest, however, that the ship on night stations (with lights on deck on the ship) frequently attracted Leach's storm petrels that came on board anywhere in the study area, but most frequently in the Agulhas ring area. This was the only species encountered on deck during all surveys.

Hardly any references appear in the literature to the dense gatherings at sea, with birds huddling together while swimming with conspecifics, let alone with other species. Ryan (1997) and Ryan and Whittington (1997) briefly mention the occurrence of mixed flocks of Leach's storm petrels and great-winged petrels at sea, but with no further comments. Some species are known to gather in rafts of thousands of individuals (Brooke 2004), but descriptions of such flocks are nowhere close to observed tight gatherings during the surveys reported in the present study. The reason for these gatherings, particularly for those where both species were involved, are not clear. Tight packs of storm petrels swimming in deep ocean waters are rather common, however (personal observations, Camphuysen and Van der Meer 2005), no matter the lack of attention in the literature. The birds are not feeding (even if individuals that left such flocks were sometimes seen to commence foraging immediately), and even although many birds leaving such flocks started an aerial display, it is difficult to imagine that social interactions between two (or three) very different species played a role. What is left as an explanation is safety, possibly safety in numbers or the confusion of predators. All three species that were engaged in these gatherings in the present study (and indeed in all observed cases known by the author) are black all over, and, hence, highly visible for potential predators under water such as large bony fish, sharks or marine mammals. The petrel family (storm petrels in particular) is well known for their frequent feet injuries, from damaged webs to missing toes and entire limbs, generally assumed to be caused by predatory fish (Harrison 1955; Pitman 1961; Threlfall 1974; Love 1984). A tight gathering of birds may look more impressive or massive from below than a single bird, and with numerous feet in a small area, the individual risk to be targeted by underwater predators may be reduced. In great-winged petrels (but not in Leach's petrels), the tendency to huddle in tight gatherings increased with sea state, 
while one would expect greater visibility (and risks) from below in calm conditions. This speculative conclusion obviously needs future investigation.

These surveys have been successful in shedding more light on the offshore distribution, behaviour, interactions and relative abundance of two petrels inhabiting the open ocean off southern Africa. Previous publications on the abundance and distribution of either species in the region were based on more fragmented material, and especially the Leach's storm petrel has been shown to be considerably more abundant andoccurred further to the south in numbers than could be anticipated from published sources (Murphy 1915; Cramp and Simmons 1977; Griffiths and Sinclair 1982; Bourne and Curtis 1985; Marchant and Higgins 1990). The interactions between two ecologically different species at sea, their co-occurrence and predilection for roosting together have been described in unprecedented detail, and the results might stimulate further research into this field in other areas and with other species.

\section{Zusammenfassung}

Wo sich zwei Ozeane treffen: Verteilung und auf-See Interaktionen von Weißkopfsturmvögeln Pterodroma macroptera und Wellenläufern Oceanodroma leucorhoa vor den Küsten des südlichen Afrika

Bei Zählungen der Seevögel auf offener See vor dem südlichen Afrika waren Weißkopfsturmvögel (Pterodroma macroptera) und Wellenläufer (Oceanodroma leucorhoa) weit verbreitet und recht häufig. Ähnliches Flugverhalten, häufige soziale Interaktionen, die Tendenz, sich in gemischten Gruppen zusammenzufinden und Interaktionen während der Nahrungssuche regten die genauere Untersuchung ihres Verhaltens und ihrer Verteilung an. Beide Arten sind am häufigsten bei Meerestiefen von $>2000 \mathrm{~m}$ mit geringere Dichte in den Flachmeerbereichen. Wellenläufer waren mit etwa 0.5 Vögeln $\mathrm{km}^{-2}$ etwa doppelt so häufig wie Weißkopfsturmvögel (ca. $0.25 \mathrm{~km}^{-2}$ ). Die Schätzungen ergeben etwa eine halbe Million Weißkopfsturmvögeln und etwa eine Million Wellenläufer im Bereich der tiefen Wasser vor dem südlichen Afrika. Die Anwesenheit von Fischkuttern erhöhte die Dichte, was andeutet, dass die Vögel Fischereiabfälle nutzen. Allerdings findet in der Region kaum Fischerei statt. Im Flachmeerbereich wurden keine Auswirkungen der Fischerei auf die Sturmvögel festgestellt. Beide Arten zeigten eine Assoziation in ihrer Verteilung zu den Agulhas Auftriebsgebieten. Hohe Dichten von Wellenläufer traten dort auf, wo es steile Gradienten in der Salinität und in der Oberflächentemperatur gab. Dies gilt nicht für Weißkopfsturmvögel. Sie fraßen vergleichsweise wenig zur Hellzeit des Tages (10,3\% der beobachteten Vögel), wogegen Wellenläufer zu 66,2\% am Tag auf Nahrungssuche ging. Weißkopfsturmvögel wurden häufig beobachtet, wie sie sich Nahrungssuchenden Wellenläufer anschlossen, wohl um von deren Sucherfahrung zu profitieren. Beide Arten zeigten Flugmanöver als Individuen, in Paaren, in größeren Gruppen und in gemischten Gruppen. Auch bildeten sie enge Schwimmgruppen, entweder artrein oder gemischt. Bei Störungen lösten sich solche Gruppen sehr schnell auf und zeigten Flugmanöver. Es wird angenommen, dass die Bildung solcher Trupps Teil einer Räuberabwehrstrategie ist gegenüber Attacken von unter Wasser.

Acknowledgments Captains John Ellen and Hans de Groot and crew of RV Pelagia are thanked for their co-operation on board. Expedition leaders Gert-Jan Brummer and Kees Veth, but also Wilco Hazeleger, Frank Peeters and Astrid van Veldhoven, are thanked for their kind help with the interpretation of oceanographical data and for information on biological activity in different water masses both during these cruises and back in the laboratories on Texel. I would like to thank my co-observer in 2000 Jaap van der Meer for pleasant company and help on board. Thanks to Mardik Leopold and Irene Tieleman for fruitful discussions and advice when the manuscript was prepared. Four anonymous referees kindly reviewed earlier versions of this manuscript and have contributed considerably to the final paper.

\section{References}

Birdlife International (2004) Tracking ocean wanderers: the global distribution of albatrosses and petrels. Results from the Global Procelariiform Tracking workshop, 1-5 September 2003, Gordon's Bay, South Africa, Birdlife International, Cambridge

Bourne WRP, Curtis WF (1985) South Atlantic seabirds. Sea Swallow 34:18-28

Brooke M (2004) Albatrosses and petrels across the world. Oxford University Press, Oxford

Buckland ST (1985) Perpendicular distance models for line transect sampling. Biometrics 41:177-195

Camphuysen CJ, Garthe S (2004) Recording foraging seabirds at sea: standardised recording and coding of foraging behaviour and multi-species foraging associations. Atl Seabirds 6:1-32

Camphuysen CJ, Meer J van der (2001) Pelagic distribution, moult and (sub-) specific status of Cory's Shearwaters Calonectris [d.] diomedea/borealis wintering off southern Africa. Mar Ornithol 29:85-93

Camphuysen CJ, Meer J van der (2005) Wintering seabirds in Western Africa: foraging hot-spots off Western Sahara and Mauritania driven by upwelling and fisheries. Afr J Mar Sci 27:427-437

Catard A, Weimerskirch H, Cherel Y (2000) Exploitation of distant Antarctic waters and close shelf-break waters by white-chinned petrels rearing chicks. Mar Ecol Prog Ser 194:249-261

Cramp S, Simmons KEL (eds) (1977) The birds of the western Palearctic, 1. Oxford University Press, Oxford

Duncan CP (1968) An eddy in the subtropical convergence southwest of South Africa. J Geophys Res 73:531-534

Elliot HFI (1957) A contribution to the ornithology of the Tristan da Cunha group. Ibis 99:545-586 
Enticott J, Tipling D (1997) Photographic handbook of the seabirds of the world. New Holland, London

Freeman AND, Nicholls DG, Wilson KJ, Bartle JA (1997) Radio- and satellite tracking Westland Petrels Procellaria westlandica. Mar Ornithol 25:31-36

Froneman PW, McQuaid CD, Laubscher RK (1999) Size-fractionated primary production studies in the vicinity of the Subtropical Front and an adjacent warm-core eddy south of Africa in austral winter. J Plankton Res 21:2019-2035

Goni GJ, Garzoli SL, Roubicek AJ, Olson DB, Brown OB (1997) Agulhas ring dynamics from TOPEX/POSEIDON satellite altimeter data. J Mar Res 55:861-883

Gordon AL (1985) Indian Atlantic transfer of thermocline water at the Agulhas retroflection. Science 222:1030-1033

Griffiths AM, Sinclair JC (1982) The occurrence of Holarctic seabirds in the African sector of the southern Ocean. Cormorant 10:35-44

Haney JC (1986a) Remote sensing of seabird environments. Am Birds 40:396-400

Haney JC (1986b) Seabird segregation at gulf stream frontal eddies. Mar Ecol Prog Ser 28:279-285

Haney JC, McGillivray PA (1985) Midshelf fronts in the South Atlantic Bight and their influence on seabird distribution and seasonal abundance. Biol Oceanogr 3:401-430

Harrison JM (1955) Fish and other aquatic fauna as predators of birds. Bull BOC 75:110-113

Harrison NM, Whitehouse MJ, Heinemann D, Prince PA, Hunt GL Jr, Veit RR (1991) Observations of multispecies seabird flocks around South Georgia. Auk 108:801-810

Harrison P (1983) Seabirds: an identification guide. Croom Helm, Beckenham

Harrison P (1987) Seabirds of the world: a photographic guide. Christopher Helm, London

Heinemann D (1981) A rangefinder for pelagic bird censusing. J Wildl Manage 45:489-493

Huntington CE, Butler RG, Mauck RA (1996) Leach's Storm-Petrel (Oceanodroma leucorhoa). In: Poole A, Gill F (eds) The birds of North America, No. 233 . The Academy of Natural Sciences, Philadelphia, PA, and The American Ornithologists' Union, Washington, DC

International Hydrographic Bureau (1953) Limits of oceans and seas. Special Publication No. 23, International Hydrographic Bureau, Monte Carlo

Lipinski MR, Jackson S (1989) Surface-feeding on cephalopods by Procellariiform seabirds in the southern Benguela region, South Africa. J Zool 218:549-563

Love JA (1984) Leg injuries in small petrels. Seabird 7:71-73

Marchant S, Higgins PJ (eds) (1990) Handbook of Australian, New Zealand and Antarctic birds, 1. Oxford University Press, Melbourne

Murphy RC (1915) The Atlantic range of Leach's Petrel Oceanodroma leucorhoa (Vieillot). Auk 32:170-173

Murphy RC (1936) Oceanic birds of South America, 1 and 2. American Mus Nat Hist., New York

Nel DC, Lutjeharms JRE, Pakhomov EA, Ansorge IJ, Ryan PG, Klages NTW (2001) Exploitation of mesoscale oceanographic features by Grey-headed Albatross Thalassarche chrysostoma in the southern Indian Ocean. Mar Ecol Progr Ser 217:15-26

Pitman CRS (1961) More aquatic predators of birds. Bull BOC 81:57-62

Prince PA, Morgan RA (1987) Diet and feeding ecology of Procellariiformes. In: Croxall JB (ed) Seabirds: feeding biology and role in marine ecosystems. Cambridge University Press, Cambridge, pp 135-171

Ridoux V (1994) The diets and dietary segregation of seabirds at the subantarctic Crozet Islands. Mar Ornithol 22:1-192

Ryan P (1997) Greatwinged Petrel, Langvlerkstormvoël Pterodroma macroptera. In: Harrison JA, Allan DG, Underhill LG, Herremans M, Tree AJ, Parker V, Brown CJ (eds) The atlas of southern African birds, 1: Non-Passerines. Bird Life S Afr, Johannesburg, p 757

Ryan P, Whittington PA (1997) Leach's storm petrel Swaelstertstormswael Oceanodroma leucorhoa In: Harrison JA, Allan DG, Underhill LG, Herremans M, Tree AJ, Parker V, Brown CJ (eds) The atlas of southern African birds, 1: non-Passerines. Bird Life S Afr, Johannesburg, pp 22-23

Serventy DL, Serventy V, Warham J (1971) The handbook of Australian sea-birds. A.H. and A.W. Reed, Sydney

Shealer DA (2002) Foraging behavior and food of seabirds. In: Schreiber EA, Burger J (eds) Biology of marine birds. CRC Press, Boca Raton, pp 137-177

Sklepkovych BO, Montevecchi WA (1989) The world's largest known nesting colony of Leach's Petrels. Am Birds 43:38-42

Sokal RR, Rohlf F (1981) Biometry. Freeman, New York

Speckman SG, Piatt JF, Springer AM (2003) Deciphering the social structure of Marbled Murrelets from behavioral observations at sea. Waterbirds 26:266-274

Stone CJ, Webb A, Barton C, Ratcliffe N, Reed TC, Tasker ML, Camphuysen CJ, Pienkowski MW (1995) An atlas of seabird distribution in north-west European waters. Joint Nature Conservation Committee, Peterborough

Tasker ML, Jones PH, Dixon TJ, Blake BF (1984) Counting seabirds at sea from ships: a review of methods employed and a suggestion for a standardized approach. Auk 101:567-577

Threlfall W (1974) Foot injuries in Leach's storm petrels. Wilson Bull 86:65-67

Underhill LG, Crawford RJM, Camphuysen CJ (2002) Leach's storm petrels Oceanodroma leucorhoa off southern Africa: breeding and migratory status, and measurements and mass of the breeding population. Trans R Soc S Afr 57:43-46

Veit RR (1999) Behavioural responses by foraging petrels to swarms of Antarctic krill: Euphausia superba. Ardea 87:41-50

Veldhoven A van (2005) Observations of the evolution of Agulhas Rings. PhD thesis, University, Utrecht

Wakker KF, Zandbergen RCA, Naeije MC, Ambrosius BAC (1990) Geostat altimeter data analysis for the oceans around South Africa. J Geophys Res 95:2991-3006

Whittington PA, Dyer BM, Crawford RJM, Williams AJ (1999) First recorded breeding of Leach's storm petrel Oceanodroma leucorhoa in the Southern hemisphere at Dyer Island, South Africa. Ibis 141:327-330 